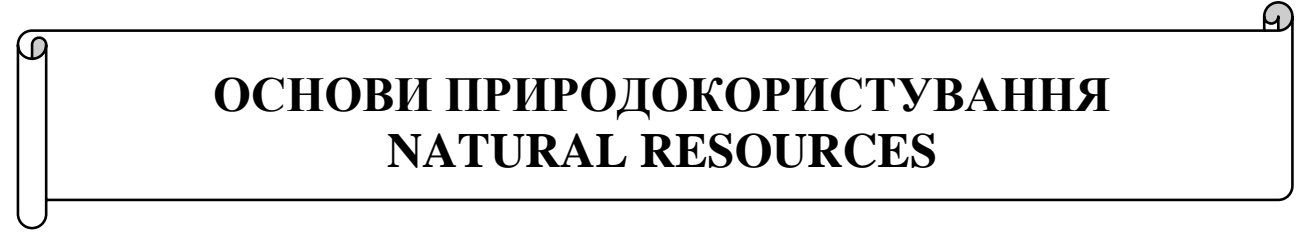

УДК 628.4

Dmitry N. Samchenko ${ }^{1}, \mathrm{PhD}$, Senior Scientist

ORCID ID 0000-0003-3305-8180 e-mail: sama30071988@gmail.com

Gennadii M. Kochetov ${ }^{1}$, D. S. (Engineering), Professor

ORCID ID 0000-0003-0041-7335 e-mail: gkochetov@gmail.com

Aleksey Vasiliev ${ }^{2}$, Dr., Professor

ORCID ID 0000-0003-2687-0672 e-mail: vasiliev@etsu.edu

${ }^{1}$ Kyiv National University of Construction and Architecture, Kyiv, Ukraine

${ }^{2}$ East Tennessee State University, Johnson City, USA

\title{
ENERGY-SAVING TECHNOLOGY FOR PROCESSING OF GALVANIC SLUDGE WITH OBTAINING OF RADIO-ABSORBING MATERIALS
}

Abstract. The prospective for increasing of environmental safety level of industrial enterprises is considered as result of realization of energy-and resource saving technology for processing galvanic sludge by hydrophase ferritisation method. The possibility of obtaining $\mathrm{Ni}-\mathrm{Cu}$-Zn ferrites by processing of galvanic sludge based on of ferritization technology has been studied. Influence of different technological parameters and activation methods of the ferritisation process: thermal and electromagnetic pulse at temperatures of $75^{\circ} \mathrm{C}$ and $20^{\circ} \mathrm{C}$, respectively, on qualitative and quantitative phase content of ferrite sediments has been experimentally determined. The method of electromagnetic pulse activation provides the appropriate degree of heavy metal ions extraction $-99.96 \%$, and also has undeniable energy advantages over thermal, since energy consumption is reduced more than $60 \%$. The efficiency of electromagnetic pulse discharges with magnetic induction amplitude of $0.298 \mathrm{~T}$ and a pulse frequency from 0.5 to $10 \mathrm{~Hz}$ to obtain environmentally friendly ferrite precipitates has been confirmed. The use of $\mathrm{Ni}-\mathrm{Cu}-\mathrm{Zn}$ ferrite powder for production of coatings that shield the electromagnetic rays in the ultrahigh frequency range is proposed. Obtained sediments have maximum content of crystalline ferromagnetic phases of ferrites - more than $93 \%$. The proposed resource-saving ferritisation process prevents environmental pollution, ensures efficient and rational use of raw materials and energy in industry, as well as allows to obtain marketable products from industrial waste.

Keywords: galvanic sludges; ferritization; electromagnetic pulse discharges; radioabsorbing materials

() Д.М. Самченко, Г.М. Кочетов, А. Васильєв, 2020

ISSN: 2411-4049. Екологічна безпека та природокористування, № 3 (35), 2020 


\title{
Д.М. Самченко ${ }^{1}$, Г.М. Кочетов ${ }^{1}$, А. Васильєв ${ }^{2}$
}

${ }^{1}$ Київський національний університет будівництва і архітектури, м. Київ, Україна

2 Державний університет Східного Теннессі, Джонсон-Сіті, США

\section{ЕНЕРГООЩАДНА ТЕХНОЛОГІЯ ПЕРЕРОБКИ ГАЛЬВАНІЧНИХ ШЛАМІВ 3 ОДЕРЖАННЯМ РАДІОПОГЛИНАЮЧИХ МАТЕРІАЛІВ}

\begin{abstract}
Анотація. Розглядається перспектива підвищення рівня екологічної безпеки промислових підприємств в результаті реалізації енерго- і ресурсозберігаючої технології переробки гальванічних иламів методом гідрофазної феритизації. Досліджено можливість отримання $\mathrm{Ni}-\mathrm{Cu}-\mathrm{Zn}$ феритів при переробиі гальванічних шламів на основі феритизачійної технології. Експериментально визначено вплив на кількісний та якісний фазовий склад феритних осадів різних технологічних параметрів переробки та способів активації процесу феритизації: термічного $i$ електромагнітного імпульсного при температурах $75^{\circ} \mathrm{C}$ i $20^{\circ} \mathrm{C}$, відповідно. Метод електромагнітної імпульсної активачії забезпечує належний ступінь вилучення іонів важких металів 99,96\%, а також має незаперечні енергетичні переваги в порівнянні 3 термічним: енергозатрати знижуються більш ніж на 60\%. Підтверджено ефективність застосування електромагнітних імпульсних розрядів 3 амплітудою магнітної індукиії 0,298 Тл та частотою імпульсів від 0,5 до 10 Ги з одержанням екологічно безпечних феритних осадів. Запропоновано використання порошкоподібного $\mathrm{Ni}-\mathrm{Cu}-\mathrm{Zn}$ фериту для виготовлення покриттів, щуо поглинають електромагнітні хвилі в надвисокочастотному діапазоні. Ферити характеризуються максимальним вмістом кристалічних феромагнітних фаз феритів - більш ніж 93\%. Запропонований ресурсозберігаючий прочес феритизачії запобігає забрудненню навколишнього середовища, забезпечує ефективне $i$ раціональне використання сировини та енергії в промисловості, а також дозволяє отримати товарні продукти з відходів виробництва.
\end{abstract}

Ключові слова: гальванічні шлами; феритизачія; електромагнітні імпульсні розряди; радіопоглинаючі матеріали

\section{Актуальність дослідження}

До найбільш екологічно небезпечних промислових відходів варто віднести металовмісні відходи гальванічних виробництв, які представлені у вигляді пастоподібних шламів [1]. Такі відходи утворюються при традиційному реагентному очищенні стічних вод або робочих розчинів. Гальванічний шлам після нейтралізації має III клас небезпеки, у його складі містяться важкорозчинні гідроксиди важких металів (нікелю, міді, цинку, хрому, кадмію), а сам шлам проявляє лужні властивості [2]. Розміщення гальванічних шламів на промислових майданчиках і на значних територіях міської зони дозволяють оцінити їх як джерело високого техногенного впливу на довкілля [3].

Переробка гальванічних шламів 3 подальшим захороненням їх на спеціальних полігонах $є$ нерентабельною, через що постає завдання розробки ефективних методів утилізації відходів, які містять цінні сполуки важких металів, як останньої завершальної стадії гальванічного виробництва. 
Повторне використання вилучених із шламів матеріалів, навпаки, дозволяє зекономити природні ресурси та понизити навантаження на екосистему [4].

Відомі способи вилучення цінних компонентів 3 гідроксидних шламів гальванічних виробництв економічно і екологічно неефективні. Тому основні напрямки у вирішенні проблеми шламів пов'язані з використанням їх в якості добавок у виробництві різних матеріалів: бетону [5], керамзиту [6], асфальту [7], портландцементу [8], цегли, керамічних виробів [9], пігментів, каталізаторів [10] і т. д. Наведені способи є екологічно безпечнішими, ніж вивезення шламів на неспеціалізовані полігони або в несанкціоновані місця складування. Проте при цьому немає достатнього аналізу санітарно-хімічної безпеки технології виробництва і готових виробів 3 добавками гальванічних шламів, що важливо для промислового впровадження [11].

3 цих причин останнім часом з'явилися публікації про новий напрямок у вирішенні проблеми переробки гальванічних шламів. Він полягає в їх хімічній стабілізації, в результаті якої утворюються нешкідливі або малотоксичні сполуки важких металів IV класу небезпеки. Їх можна складувати на відкритих майданчиках без загрози забруднення навколишнього середовища. Такими сполуками можуть бути ферити, які мають цінні магнітні властивості [12]. Крім того, ферити спроможні до екозахисту живих організмів від електромагнітного випромінювання. Інтерес до феритів викликаний все зростаючим попитом на вироби з високочастотних магнітних матеріалів, які широко застосовуються в сучасному машинобудуванні, приладобудуванні, системах управління, сучасних автоматизованих лініях та космічній промисловості. Широке використання феритів накладає ряд вимог на характеристики їх одержування. При виробництві феритних матеріалів велика увага приділяється отриманню феритів певного фазового складу.

Останнім часом все більшим попитом користуються Ni-Zn феритові матеріали, які поглинають електромагнітне випромінювання в інтервалі частот менше 1 ГГц за рахунок резонансних явищ [13]. Зазначені матеріали використовуються для виготовлення акустичних камер, магнітних екранів i захисних радіопоглинаючих покриттів. Покриття $3 \mathrm{Ni}-\mathrm{Zn}$ феритових матеріалів захищає об'єкти військової авіації від виявлення локаторами. Крім того, авторами досліджень [14] розроблений новий склад радіопоглинаючого $\mathrm{Ni}-\mathrm{Cu}-\mathrm{Zn}$ ферита 3 коефіцієнтом відображення при частоті поля 1000 МГц в 36 ДБ. Магнітні властивості нанокристалічних $\mathrm{Ni}-\mathrm{Cu}-\mathrm{Zn}$ феритів досліджені в роботі авторів [15]. Такі ферити мають високу проникність і досить високу радіочастотну добротність. На думку авторів [16, 17], саме феритові радіопоглинаючі матеріали повинні бути розглянуті якнайретельнішим чином при вирішенні питання про захист від випромінювань сучасної техніки.

На теперішній час відомі різноманітні методи одержання різних типів феритів [18-20]. Традиційні технології синтезу феритів базуються на твердофазній взаємодії оксидів, гідроксидів або солей важких металів і мають певні недоліки. Вони енергетично високозатратні: процес випалу та спікання здійснюється вище $1200^{\circ} \mathrm{C}$ і триває в межах $4 \div 5$ годин [21, 22].

На відміну від зазначених вище методів одержання феритів, переробка гальванічних шламів гідрофазною феритизацією, як правило, здійснюється при температурі процесу вище $75^{\circ} \mathrm{C}$ та тривалістю менше години. Цей метод синтезу феритів порівняно 3 попередньо зазначеними методами $є$ доволі енергоощадним, але водночас залишається енергоємним та ресурсозатратним. 
Альтернативою гідрофазній термічній активації може слугувати активація електромагнітними імпульсними (EMI) розрядами при температурі процесу близько $20^{\circ} \mathrm{C}$. Тому на часі всебічне дослідження економічно ефективної переробки гальванічних шламів, яка забезпечує необхідний ефект вилучення іонів важких металів 3 реакційної суміші в екологічно безпечні та цінні сполуки феритів.

Метою цієї роботи є дослідження структурних особливостей одержаних феритних осадів в процесі переробки гальванічних шламів гідрофазною феритизацією при різних параметрах та способах їх отримання.

\section{Методика дослідження}

Для дослідження використовувалися зразки феритних осадів, отримані в процесі переробки відпрацьованого сірчанокислотного розчину травлення сталі та згущеного гальванічного шламу, який $є$ відходом реагентної очистки відпрацьованих електролітів нікелювання, міднення і цинкування. Основні характеристики цих гальванічних відходів представлено в табл. 1 і 2. Феритизаційний процес включає трансформацію іонів дво- і тривалентного феруму (травильний розчин) та інших гідроксидів важких металів (гальванічний шлам) в лужному середовищі $з$ подальшою аерацією киснем повітря. В якості осаджувача використовували $25 \%$ розчин гідроксиду натрію. Після синтезу був отриманий набір зразків феритних осадів 3 певним хімічним складом.

Таблиця 1 - Основні характеристики гальванічного шламу нейтралізації

\begin{tabular}{|c|c|c|c|c|c|c|c|}
\hline \multicolumn{2}{|c|}{ Вміст іонів важких металів, г/дм } & \multirow{2}{*}{$\mathrm{pH}$} & $\begin{array}{c}\text { Густина } \\
(\rho), \Gamma / \mathrm{cm}^{3}\end{array}$ & $\begin{array}{c}\text { Вологість } \\
(\mathrm{W}), \%\end{array}$ & $\begin{array}{c}\text { Сухий залишок, } \\
\text { мг/дм }\end{array}$ \\
\cline { 1 - 3 } $\mathrm{Fe}^{3 \mathrm{ar} .}$ & $\mathrm{Ni}^{2+}$ & $\mathrm{Cu}^{2+}$ & $\mathrm{Zn}^{2+}$ & & 1,016 & 93,06 & 3040 \\
\hline 0,203 & 4,732 & 2,631 & 1,425 & 9,81 & 1,06 & \\
\hline
\end{tabular}

Таблиця 2 - Характеристики відпрацьованого сірчанокислотного травильного розчину

\begin{tabular}{|l|c|c|c|c|}
\hline Матеріал травлення & $\mathrm{H}_{2} \mathrm{SO}_{4}, \Gamma /$ дм$^{3}$ & $\mathrm{Fe}^{3 \mathrm{ar}}, \Gamma /$ дм$^{3}$ & $\mathrm{SO}_{4}{ }^{2-}, \Gamma /$ дм$^{3}$ & $\mathrm{pH}$ \\
\hline Сталеві труби & 41,0 & 46,6 & 79,89 & 1,45 \\
\hline
\end{tabular}

Для визначення умов утворення феритів металів були проведені експерименти 3 вивчення впливу різних технологічних параметрів та способів активації процесу феритизації. Зразки феритних осадів отримані при наступних технологічних параметрах проходження процесу переробки, а саме: сумарна концентрація іонів важких металів $\mathrm{C}_{\Sigma}=5,3 \div 20,0$ г/дм ${ }^{3}$, співвідношення концентрацій іонів $\left[\mathrm{Fe}^{\text {заг. }}\right] / \Sigma \mathrm{Me}\left(\left[\mathrm{Ni}^{2+}\right]+\left[\mathrm{Cu}^{2+}\right]+\left[\mathrm{Zn}^{2+}\right]\right) \mathrm{Z}=2 \div 6$; величина $\mathrm{pH}=8,5 \div 10,5$; тривалість процесу $\tau=25$ хв. Швидкість аерації (v) сягала значення $0,15 \mathrm{~m}^{3} /$ год. Крім того, осади отримані при термічній $\left(\mathrm{T}=75^{\circ} \mathrm{C}\right)$, a також електромагнітній імпульсній $\left(\mathrm{T}=20 \pm 2^{\circ} \mathrm{C}\right)$ активації процесу феритизації 3 амплітудою магнітної індукції 0,298 Тл, частотою імпульсів $0,5 \div 10$ Гц, тривалістю імпульсу $50 \div 1000$ мс і інтервалом між імпульсами $50 \div 1000$ мс [23]. 
Процес отримання феритних осадів проводився на двох лабораторних установках, які представлені в роботі $[23,24]$. Вологість висушених феритних осадів знаходиться в діапазоні $1,2 \div 1,9 \%$.

Феритні осади після осадження відразу відфільтровувались, висушувались при $105^{\circ} \mathrm{C}$ протягом 1 доби та подрібнювались у порошок. Процес ущільнення осадів здійснювався методом центрифугування за допомогою центрифуги ОПн-8 (Дастам М, Росія) при факторі розділення (Фр) 3600 протягом 2 хв. Частота обертання ротера становила 6000 об/хв.

Структурний аналіз отриманих осадів проводили методом порошкової рентгенівської дифракції в покроковому режимі з $\mathrm{Cu}-\mathrm{K} \alpha$ випромінюванням на дифрактометрі Ultima IV (Rigaku, Японія). Зйомку проводили в інтервалі кутів $2 \theta 6-70^{\circ}$ з кроком сканування $0,05^{\circ}$ та часом експозиції в точці 2 с. Аналіз одержаних спектрів проводився на програмному комплексі PowderCell 2.4. Параметр кристалічної гратки (а) визначали в прецизійній області кутів.

Для вивчення мікроструктури зразків осадів використовували скануючий електронний мікроскоп-аналізатор PEMMA-101A (SELMI, Україна).

Залишкові концентрації іонів важких металів (феруму, нікелю, міді і цинку) після переробки гальванічних шламів методом феритизації визначали на спектрофотометрі DR 3900 (Hach, США).

\section{Результати дослідження}

В процесі феритизації при різних іiі способах активації та технологічних параметрах в розчині формувалась чорна дисперсна суспензія із наступним утворенням кристалічних осадів, які мають невеликий об'єм і щільну структуру. 3 наявних даних про механізм процесу феритизації слід очікувати досить складний фазовий склад отриманих осадів, оскільки можуть бути присутні різні модифікації оксидів і оксигідратів феруму, нікелю, міді та цинку, а також частинки фаз, які за своєю природою є феромагнітними, але завдяки малим розмірам мають парамагнітні властивості [25].

Проведено дослідження якісного та кількісного фазового складу зразків феритних осадів, що отримані в результаті переробки гальванічних шламів при термічній і електромагнітній імпульсній активації та величинах $\mathrm{pH}(8,5 \div 10,5)$. Інші технологічні параметри феритизації були незмінними: $\mathrm{C}_{\Sigma}(5,3 \div 20,0$ г/дм³ $)$; $\mathrm{Z}=4 / 1 ; \tau=25 \mathrm{xв} ; \mathrm{v}=0,150 \mathrm{~m}^{3} /$ год. Ідентифікація фаз в отриманих зразках показала, що в них містяться ферити металів, склад яких відповідає загальній формулі $\mathrm{Ni}_{0,53} \mathrm{Cu}_{0,3} \mathrm{Zn}_{0,17} \mathrm{Fe}_{2} \mathrm{O}_{4}$. Виявлені феритні фази мають феромагнітні властивості. Отримані ферити важких металів на відміну від їх гідроксидів не розчиняються при звичайній температурі не лише у воді, але і в розбавлених водних розчинах сильних мінеральних кислот і їдких лугів, що обумовлено особливою будовою їх кристалічної решітки шпінельного типу [26, 27]. Крім того, нами відмічені піки, які відносяться до фази оксигідроксида феруму нікелю, а саме нікелевого лимоніту (FeNi)OOH 3 a $=2,96 \AA$, який $є$ менш стабільним в порівнянні 3 феритами металів, але також має феромагнітні властивості. На рентгенограмах ідентифіковані також піки фази сульфату натрію $\mathrm{Na}_{2} \mathrm{SO}_{4} 3 \mathrm{a}=5,84 \AA$, який знаходиться в осаді у незначній кількості. Його присутність пояснюється тим, що зразки отриманих феритних осадів не піддавалися попередньому промиванню дистильованою водою. 
Результати кількісного фазового аналізу зразків осадів (рис. 1) свідчать про те, що підвищення $\mathrm{pH}$ вихідного розчину в діапазоні значень від 8,5 до 10,5 призводить до збільшення феритної фази в осадах: при термічному способі активації на 24,0\%, електромагнітному імпульсному - на 36,7\%. Це в свою чергу сприяє зменшенню вмісту нікелевого лимоніту (FeNi)OOH на 19,1\% при термічній і на 27,2\% при електромагнітній імпульсній активації, також сульфату натрію $\mathrm{Na}_{2} \mathrm{SO}_{4}$ на 5,4\% і 9,5\%, відповідно. Слід відмітити, що зразки, які отримані при $\mathrm{pH}=10,5$ і різних способах активації, мають ідентичний якісний фазовий склад, а кількісний відрізняється лише на 1,0\%.

a)

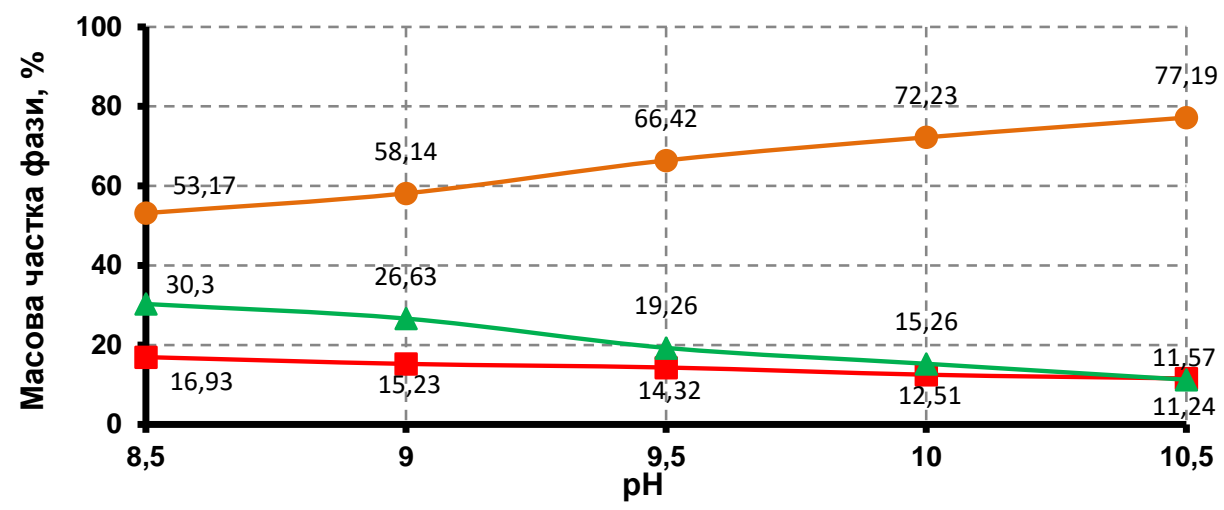

б)

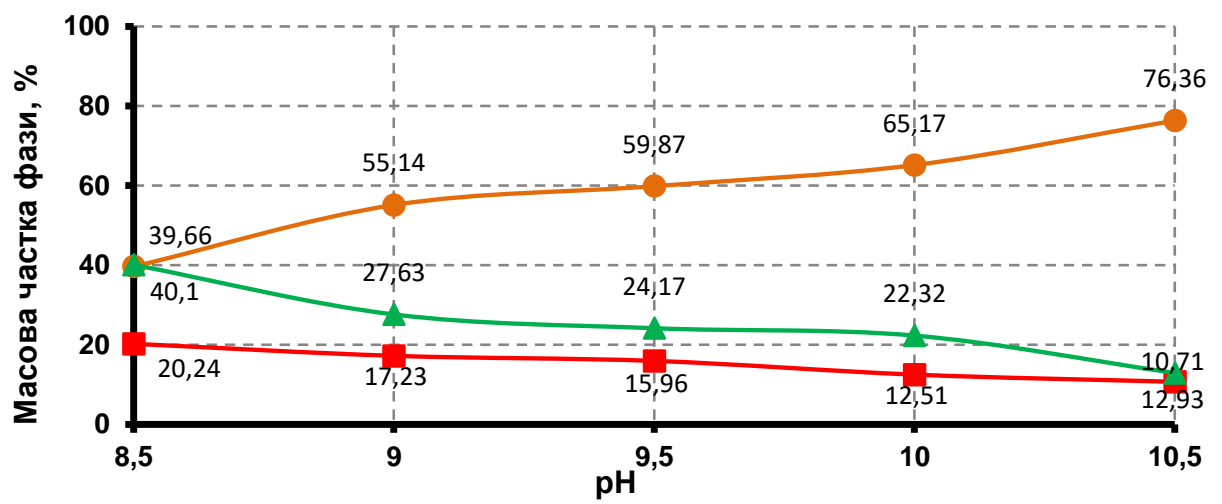

Рис. 1 - Кількісний фазовий склад феритних осадів в залежності від величини $\mathrm{pH}$ : термічна активація процесу (а), електромагнітна імпульсна активація процесу (б); $-\mathrm{Ni}_{0,53} \mathrm{Cu}_{0,3} \mathrm{Zn}_{0,17} \mathrm{Fe}_{2} \mathrm{O}_{4} ; \Delta-(\mathrm{FeNi}) \mathrm{OOH} ;-\mathrm{Na}_{2} \mathrm{SO}_{4}$

Аналіз структурних досліджень, які представлені на рис. 1, свідчить про те, що зразки, які отримані при термічній і електромагнітній імпульсній активації i $\mathrm{pH}=10,5$, характеризуються максимальним вмістом фази фериту металу $>76 \%$.

Також було проведено структурні дослідження зразків осадів, в залежності від співвідношення іонів важких металів $\mathrm{Z}(2 / 1 \div 6 / 1)$ (рис. 2). Інші сталі технологічні параметри феритизації: $\mathrm{C}_{\Sigma}\left(10,4\right.$ г/дм $\left.{ }^{3}\right) ; \mathrm{pH}=10,5 ; \tau=25$ хв; $\mathrm{v}=0,150 \mathrm{~m}^{3} /$ год.

Рентгенограми зразків $3 \mathrm{Z}=4 / 1$, які отримані при термічній та електромагнітній імпульсній активації, практично співпадають, а різниця 
інтенсивності рефлексів несуттєва. Ці зразки мають найбільший ступінь кристалічності структури, в них виявлені такі ж фази, які індентифіковані при дослідженні впливу величини рН на структуру осаду (рис. 1).

Результати кількісного фазового аналізу зразків (рис. 2) свідчать про те, що підвищення співвідношення концентрації важких металів Z у вихідному розчині від 2/1 до 4/1 призводить до збільшення фаз феритів металів в осадах: при термічному способі активації на $12,2 \%$, електромагнітному імпульсному 19,7\%. Це в свою чергу сприяє зменшенню фази нікелевого лимоніту на 8,5\% при термічній активації і на 12,9\% при електромагнітній імпульсній. Відповідні значення для сульфату натрію складають 3,7\% і 6,7\%. При подальшому підвищенні Z вихідного розчину від 4/1 до 6/1 зменшується вміст феритних фаз в осадах: при термічному способі активації на 8,0\%, електромагнітному імпульсному - на 26,5\% і відповідне збільшення фаз: (FeNi)OOH на 4,9\% і 19,2\%; $\mathrm{Na}_{2} \mathrm{SO}_{4}$ на 1,1\% і 7,3\%.

a)

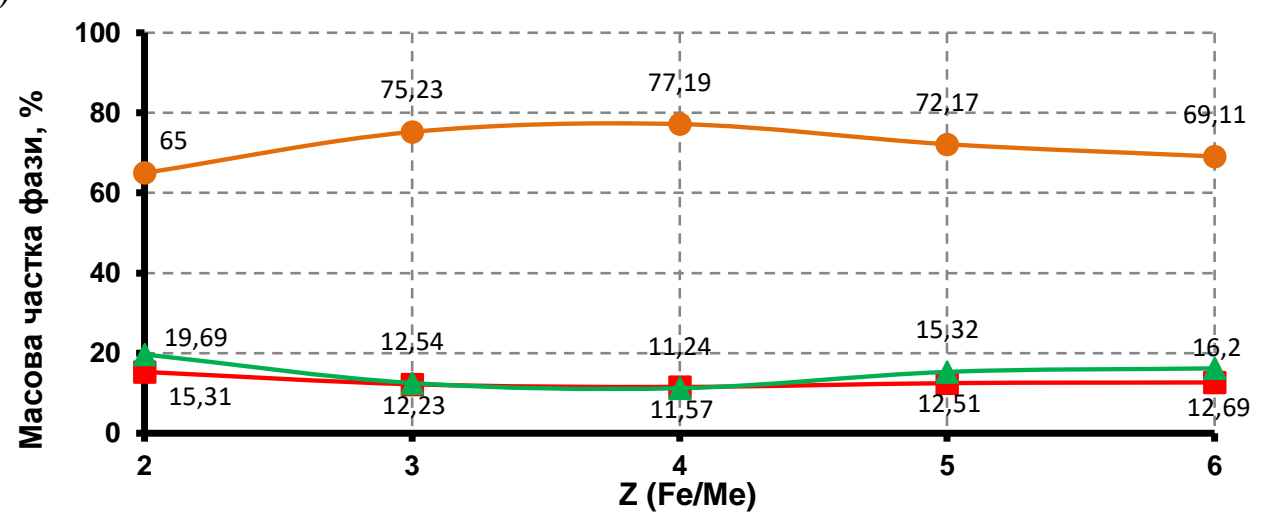

б)

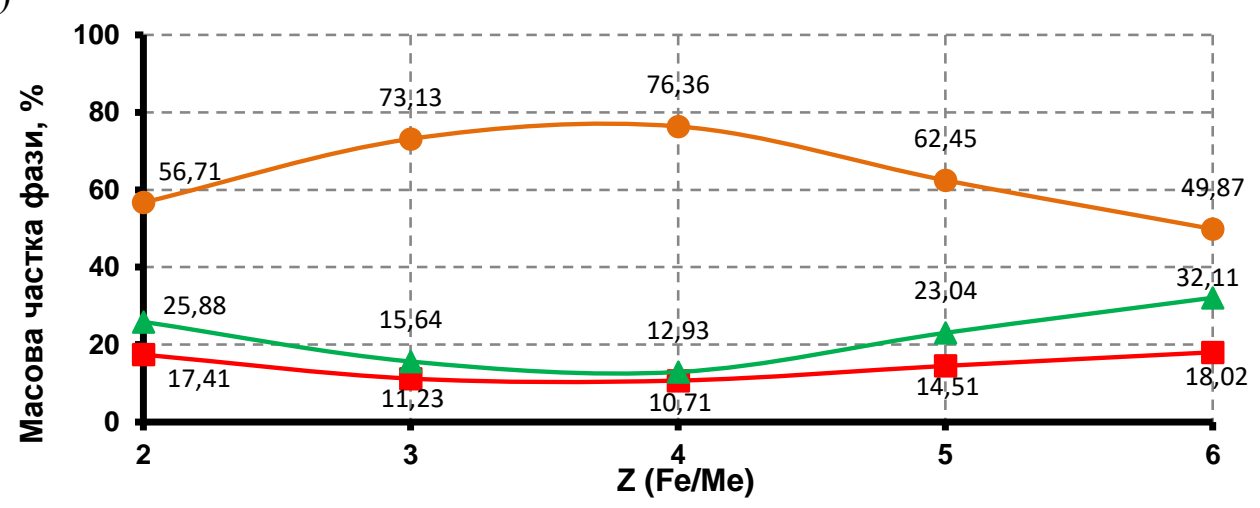

Рис. 2 - Кількісний фазовий склад осадів в залежності від співвідношення концентрації іонів важких металів Z: термічна активація процесу (a), електромагнітна імпульсна активація процесу (б); - $\mathrm{Ni}_{0,53} \mathrm{Cu}_{0,3} \mathrm{Zn}_{0,17} \mathrm{Fe}_{2} \mathrm{O}_{4}$;

$\triangle-(\mathrm{FeNi}) \mathrm{O}(\mathrm{OH}) ;-\mathrm{Na}_{2} \mathrm{SO}_{4}$

Проведені структурні дослідження (рис. 2) дозволяють обгрунтувати, чому найкращі результати досягаються при співвідношенні 4/1. На наш погляд, це пов'язано з тим, що при інших значеннях Z, крім утворення феритної фази, 
в розчині протікають проміжні твердофазні реакції. Таким чином, утворюються обмежено стійкі в лужному середовищі фази [28], що i призводить до певного збільшення залишкової концентрації іонів нікелю.

Крім того, було проведено дослідження структури осадів, які отримані при різних вихідних концентраціях іонів важких металів $C_{\Sigma}=5,3 \div 20,0$ г/дм ${ }^{3}$ та способах активації процесу феритизації (рис. 3). Інші технологічні параметри феритизації залишались сталими, а саме: $\mathrm{Z}=4 / 1 ; \mathrm{pH}=10,5$. Структурні дослідження феритних осадів свідчать про їх високу кристалічність за виключенням зразка з $\mathrm{C}_{\Sigma}=20,0$ г/дм³ , який отримано при електромагнітній імпульсній активації процесу. Дифракційні максимуми цього зразка розширені і мають незначну інтенсивність. Ідентифікація фаз зразків осадів показала, що в них містяться ферити металів, оксигідроксиди феруму та нікелю. Крім того, в зразках з $\mathrm{C}_{\Sigma}=20,0$ г/дм ${ }^{3}$ нами виявлено дифракційні максимуми, які відносяться до фази лепідокрокіту $\gamma-\mathrm{FeO}(\mathrm{OH})$, який також $є$ феромагнітним компонентом осаду. На рентгенограмах були виявлені також піки сульфату натрію.

a)

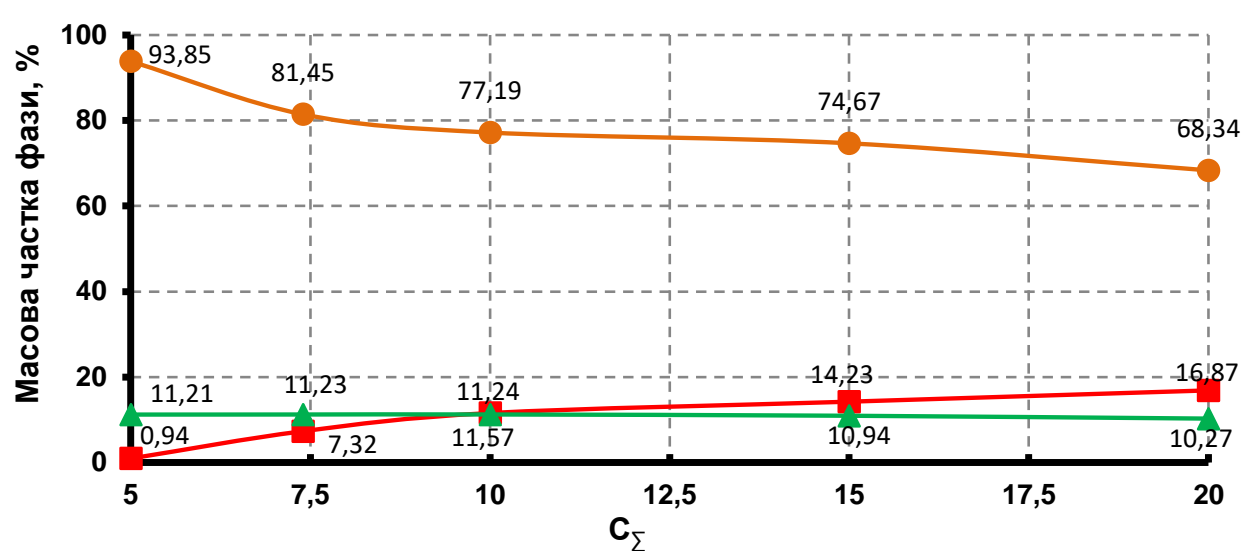

б)

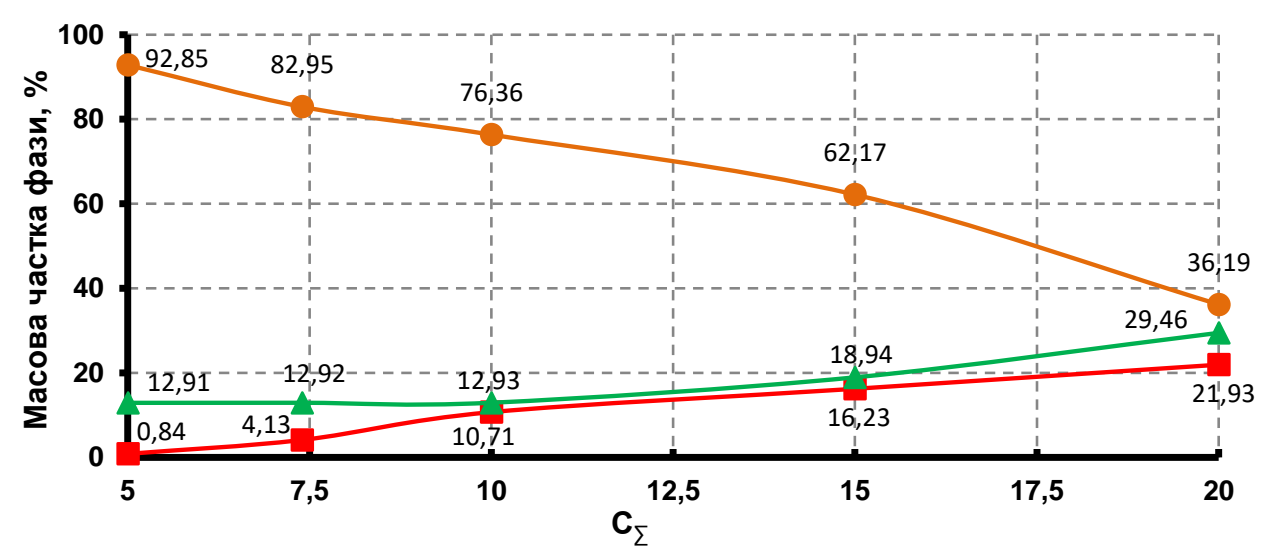

Рис. 3 - Кількісний фазовий склад осадів в залежності від вихідної сумарної концентрації важких металів $\mathrm{C}_{\Sigma}$ : термічна активація процесу (а), електромагнітна імпульсна активація процесу (б); - $\mathrm{Ni}_{0,53} \mathrm{Cu}_{0,3} \mathrm{Zn}_{0,17} \mathrm{Fe}_{2} \mathrm{O}_{4} ;{ }^{-}-(\mathrm{FeNi}) \mathrm{O}(\mathrm{OH})$;

$-\mathrm{Na}_{2} \mathrm{SO}_{4}$ 
Результати кількісного фазового аналізу зразків осадів (рис. 3) свідчать про те, що підвищення вихідної концентрації іонів металів $\mathrm{C}_{\Sigma}$ в діапазоні значень від 5,3 до 20,0 г/дм ${ }^{3}$ в розчині призводить до зменшення феритних фаз в осадах: при термічному на 25,5\%, електромагнітному імпульсному - 56,7\%. За цих умов відбувається незначне зменшення фази нікелевого лимоніту при термічній на 0,9\% та збільшення цієї фази при електромагнітному імпульсному на $16,5 \%$. Крім того, при високих значеннях $\mathrm{C}_{\Sigma}=20,0$ г/дм ${ }^{3}$ ідентифіковано фазу лепідокрокіту $\gamma$ - $\mathrm{FeO}(\mathrm{OH})$ в кількості 4,5\% при термічній та значеннях $\mathrm{C}_{\Sigma}=15,2 \div 20,0$ г/дм 3 електромагнітною імпульсною активацією $-2,7$ та $12,4 \%$ відповідно. Слід зазначити, що підвищення $\mathrm{C}_{\Sigma}$ сприяє до збільшення фази сульфату натрію: термічному на $15,9 \%$; електромагнітному імпульсному $21,1 \%$.

Аналіз структурних досліджень отриманих осадів (рис. 1-3) засвідчив, що зразки, які отримані при термічному і електромагнітному імпульсному способі активації та технологічних параметрах феритизації $\left(\mathrm{C}_{\Sigma}=5,3\right.$ г/дм ${ }^{3} ; \mathrm{Z}=4 / 1$; $\mathrm{pH}=10,5 ; \tau=25 \mathrm{xв} ; v=0,15 \mathrm{~m}^{3} /$ год) характеризуються максимальним вмістом фаз феритів $\geq 93 \%$. Вплив різних способів активації на фазовий склад осадів не суттєвий при зазначених умовах проведення процесу феритизації. Отримані при цих умовах ферити мають високі значення магнітних властивостей та можуть використовуватися як сировина для виготовлення радіопоглинаючих покриттів.

Дані рентгенофазового аналізу добре корелюють 3 результатами електронної мікроскопії осадів (рис. 4); дослідження провадилось на зразках осадів, які отримані при визначених нами найкращих умовах феритизації: $\mathrm{C}_{\Sigma}=5,3$ г/дм ${ }^{3} ; \mathrm{Z}=4 / 1 ; \mathrm{pH}=10,5 ; \tau=25 \mathrm{xв} ; \mathrm{v}=0,15 \mathrm{~m}^{3} /$ год [24].

a)

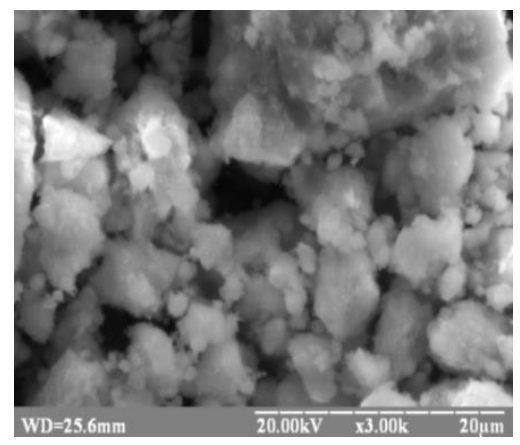

б)

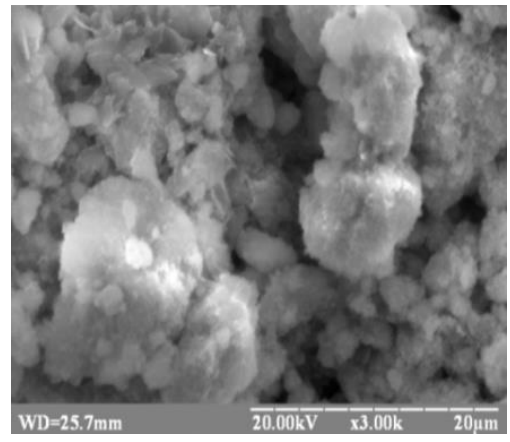

Рис. 4 - Мікрофотографії зразків осадів з термічною (а) та електромагнітною імпульсною (б) активацією; збільшення в 3000 разів

Як видно з рис. 4, в процесі переробки гальванічних шламів феритизацією при різних способах активації процесу формується осад 3 дисперсною структурою, а зразки осадів містять кристали неправильної форми в поровому просторі.

Результатами дослідження встановлено, що при застосуванні електромагнітного імпульсного та термічного способів активації і зазначених вище технологічних параметрах феритизації ступінь вилучення іонів важких металів в середньому сягає 99,96\%. При цих умовах залишкові концентрації іонів важких металів досягають значень: $\mathrm{Fe}^{\text {заг. }}-0,1 ; \mathrm{Ni}^{2+}-0,22 ; \mathrm{Cu}^{2+}-0,1$; 
$\mathrm{Zn}^{2+}-0,1 \mathrm{мг} /$ дм $^{3}$. Якість очищеного розчину відповідає вимогам до води, що використовується на гальванічному виробництві, та умовам скиду в міську каналізацію, щодо ГДК зазначених іонів важких металів.

Слід зазначити, що важливою перевагою електромагнітного імпульсного способу активації $\epsilon$ його енергоефективність. В результаті приведених розрахунків встановлено, що електромагнітний імпульсний спосіб активації процесу феритизації дає можливість на 60\% зменшити витрати електроенергії при обробці реакційної суміші в порівнянні з термічною активацією.

\section{Висновки та перспективи подальших досліджень}

Одне із перспективних рішень науково-технічної задачі забезпечення ефективного захисту різних об'єктів від електромагнітного випромінювання дозволяє отримати розроблена нами ресурсозберігаюча феритизаційна технологія переробки гальванічних шламів з одержанням радіопоглинаючих феритів важких металів. Застосування електромагнітного імпульсного способу активації реакційної суміші в процесі феритизації дає можливість істотно знизити температуру синтезу отриманих феритів $\left(\mathrm{Ni}_{0,53} \mathrm{Cu}_{0,3} \mathrm{Zn}_{0,17} \mathrm{Fe}_{2} \mathrm{O}_{4}\right)$, які характеризуються максимальним вмістом магнітних фаз (більше ніж 93\%).

Таким чином, при переробці гальванічних шламів, які містять токсичні сполуки важких металів, за розробленою технологією феритизації отримується водний розчин із вмістом іонів важких металів в межах $0,1 \div 0,22 \mathrm{мг/дм}{ }^{3}$ та ступенем їх вилучення, що перевищує 99,96\%. Очищена вода придатна для повторного використання на гальванічному виробництві (наприклад, при промиванні деталей після осадження на них нікелевих, мідних, цинкових та інших гальванічних покриттів). Отриманий осад в результаті феритизаційної переробки після просушування може використовуватись як цінний феритний порошок.

Розроблена технологія переробки гальванічних шламів майже безвідходна, оскільки передбачає використання осаду феритизації у вигляді сировини для отримання радіопоглинаючих матеріалів.

В подальшому вважаємо за доцільне дослідити отриманий нами ферит $\mathrm{Ni}_{0,53} \mathrm{Cu}_{0,3} \mathrm{Zn}_{0,17} \mathrm{Fe}_{2} \mathrm{O}_{4}$ на коефіцієнт поглинання електромагнітної енергії при різній високій частоті поля $1 \div 30$ ГГц. Крім того, подальші дослідження можуть бути спрямовані на розробку радіопоглинаючих будівельних оздоблювальних матеріалів на основі отриманих феритів, за запропонованою технологією.

\section{СПИСОК ЛІТЕРАТУРИ}

1. Boshnyak M.V. Evaluation of the processing opportunity of galvanic production sludges with nickel recovery / M.V., Boshnyak, A.R., Galimianov, O.B. Kolmachikhina // Solid State Phenomena, 2018. - Vol. 284. - P. 790-794.

2. Pashayan A.A. Recycling of electroplating wastes without formation of galvanic sludges / A.A., Pashayan, D.A. Karmanov // Ecology and Industry of Russia, 2018. - Vol. 22(12). P. 19-21.

3. de Oliveira C.L.M. Characterization of galvanic sludges waste derived of the metal plating industry from Cariri region, Northeastern of Brazil / C.L.M., de Oliveira, F.J.P., Filho, J.V.B., Moura, D.M.G., Freitas, M.O., Santiago // Materials Science Forum, 2018. - Vol. 930 MSF. - P. 541-545. 
4. Zlebek T. Repairing composite using hazardous waste containing heavy metals / T., Zlebek, J., Hodul, R., Drochytka // IOP Conference Series: Materials Science and Engineering, 2018. - Vol. 385(1). - P. 68-74.

5. Król A. Effect of high temperature on immobilization of heavy metals in concrete with an addition of galvanic sludge // WIT Transactions on Ecology and the Environment, 2008. Vol. 109. -P. 331-339.

6. González-Corrochano B. Valorization of washing aggregate sludge and sewage sludge for lightweight aggregates production / B., González-Corrochano, J., Alonso-Azcárate, L., Rodríguez, M.D., Corvinos, C., Muro // Construction and Building Materials, 2016. Vol. 116. - P. 252-262.

7. Bednarik V. Stabilization/solidification of galvanic sludges by asphalt emulsions / V., Bednarik, M., Vondruska, M., Koutny // Journal of Hazardous Materials, 2005. Vol. 122 (1-2). - P. 139-145.

8. Krivenko P. Design of the composition of alkali activated Portland cement using mineral additives of technogenic origin / P., Krivenko, O., Petropavlovsky, O., Kovalchuk, A., Pasko, S., Lapovska // Eastern-European Journal of Enterprise Technologies, 2018. - Vol. 4/6 (94). P. 6-15.

9. Castañeda Bocanegra J.J. Encapsulation in ceramic material of the metals $\mathrm{Cr}, \mathrm{Ni}$, and $\mathrm{Cu}$ contained in galvanic sludge via the solidification/stabilization method / J.J., Castañeda Bocanegra, E., Espejo Mora, G.I., Cubillos González // Journal of Environmental Chemical Engineering, 2017. - Vol. 5 (4). - P. 3834-3843.

10. Ol'shanskaya L.N. Recycling of Heavy Metals and Their Compounds from Galvanic Sludges to Produce Pigments and Fillers and the Active Species of Nickel-Iron (Cadmium) Battery Cathodes / L.N., Ol'shanskaya, E.N., Lazareva, L.A., Bulkina // Chemical and Petroleum Engineering, 2016. - Vol. 52(1-2). - P. 138-142.

11. Vilarinho C. Effect of time and acid concentration on metal extraction from galvanic sludges / C., Vilarinho, J., Teixeira, J., Araújo, J., Carvalho // ASME International Mechanical Engineering Congress and Exposition, Proceedings (IMECE), 2017. - Vol. 14. P. 713-720.

12. Kumar M. Biopolymer modified transition metal spinel ferrites for removal of fluoride ions from water / M., Kumar, H.S., Dosanjh, H., Singh // Environmental Nanotechnology, Monitoring and Management, 2019. - Vol. 12. - P. 237-245.

13. Аргымбек Б.К. Кристаллическая и магнитная структура гранулированных порошков Mn-Zn- и Ni-Zn-ферритов шпинелей / Б.К., Аргымбек, С.Е., Кичанов, Д.П., Козленко, Е.В., Лукин // Физика твердого тела, 2018. - том 60(9). - С. 1683-1688. 14. Костишин В.Г., Кожитов Л.В., Вергазов Р.М., Андреев В.Г., Морченко А.Т. Радиопоглощающий феррит. Патент РФ № 2417268 от 27.04.2011 г.

15. Hua S. Effects of nanocrystalline ferrite pattieles on densification and magnetic properties of the Ni-Cu-Zn ferrites / S., Hua, Z., Huaiwu, T., Xiaoli, L., Yingli // J. Mates. Sci, 2007. Vol. 42.- P. 2849-2853.

16. Kolev S. Nanosized Ferrite Materials for Absorption of and Protection from MW Radiation / S., Kolev, T., Koutzarova // Advanced Nanotechnologies for Detection and Defense against CBRN Agents, 2018. - P. 273-284.

17. Özgür Ü. Microwave ferrites, part 1: fundamental properties / Ü., Özgür, Y., Alivov, H., Morkoç // Journal of Materials Science: Materials in Electronics, 2009. - Vol. 20. № 9. P. 789-834.

18. Gomes J.A. Structural, chemical, and magnetic investigations of core-shell zinc ferrite nanoparticles / J.A., Gomes, G.M., Azevedo, J., Depeyrot, J., Mestnik-Filho, F.L. Paula // The Journal of Physical Chemistry, 2012. - Vol. 116 (45). - P. 24281-24291.

19. Grasset F. Etourneau. Synthesis and Magnetic Characterization of Zinc Ferrite Nanoparticles with Different Environments: Powder, Colloidal Solution, and Zinc Ferrite-Silica Core-Shell Nanoparticles / F., Grasset, N., Labhsetwar, D., Li, D. C., Park, N., Saito, H., Haneda, O., Cador, T., Roisnel, S., Mornet // Langmuir, 2002. - Vol. 18 (21). P. 8209. 
20.Zhang R. Sol-gel auto-combustion synthesis of zinc ferrite for moderate temperature desulfurization / R., Zhang, J., Huang, J., Zhao, Z., Sun, Y., Wang // Energy Fuels, 2007. 21. - P. 2682-2687.

21. Kong L.B. Progress in synthesis of ferroelectric ceramic materials via high-energy mechanochemical technique / L.B., Kong, T.S., Zhang, J., Ma, F., Boey // Progress in Materials Sci., 2008. - 53. - P. 207-213.

22. Chen D.H. Synthesis of nickel ferrite nanoparticles by sol-gel method / D.H., Chen, X.R., He // Mater. Res. Bull., 2001. - 36. - P. 1369-1377.

23. Kochetov G. M. Development of ferritization processing of galvanic waste with energy saving electromagnetic pulse activation of the process / G. M., Kochetov, T. O., Prikhna, D. M., Samchenko, O. Yu., Kovalchuk // Eastern-European Journal of Enterprise Technologies, 2019. - 6/10 (102). - P. 6-14.

24. Kochetov G. Research of the treatment of depleted nickel-plating electrolytes by the ferritization method / G., Kochetov, T., Prihna, O., Kovalchuk, D., Samchenko // EasternEuropean Journal of Enterprise Technologies, 2018. - Vol. 3 (6-93). - P. 52-60.

25. Frolova L.A. Structure and properties of nickel ferrites produced by glow discharge in the $\mathrm{Fe}^{2+}-\mathrm{Ni}^{2+}-\mathrm{SO}_{4}{ }^{2-}-\mathrm{OH}^{-}$system / L. A., Frolova, A. A., Pivovarov, A. S., Baskevich // Russ J Appl Chem, 2014. - 87(8). - P. 1054-1059.

26. Pecharsky V. K. Fundamentals of powder diffraction and structural characterization of materials / V. K., Pecharsky, P. Y., Zavalij // 2nd ed.; Springer: New York, 2009. P. 741.

27. Rodenas L.G. Reactivity of metal oxides: Thermal and photochemical dissolution of MO and $\mathrm{MFe}_{2} \mathrm{O}_{4}(\mathrm{M}=\mathrm{Ni}, \mathrm{Co}, \mathrm{Zn}) /$ L.G., Rodenas, M.A., Blesa, P.J., Morando // Reactivity Journal of Solid State Chemistry, 2008. - 181.- P. 2350-2358.

28. Mansour A. X-Ray Absorption Spectra and the Local Structure of Nickel in Some Oxycompounds and Fluorides / A., Mansour, C., Melendres // Journal de Physique IV Colloque, 1997. - 7 (C2). - P. 1171-1176.

Стаття надійшла до редакиії 28.05.2020 і прийнята до друку після рецензування 15.07.2020

\section{REFERENCES}

1. Boshnyak, M.V., Galimianov, A.R., \& Kolmachikhina, O.B. (2018). Evaluation of the processing opportunity of galvanic production sludges with nickel recovery. Solid State Phenomena, 284, 790-794.

2. Pashayan, A.A., \& Karmanov, D.A. (2018). Recycling of electroplating wastes without formation of galvanic sludges. Ecology and Industry of Russia, 22 (12), 19-21.

3. de Oliveira, C.L.M., Filho, F.J.P., Moura, J.V.B., Freitas, D.M.G., \& Santiago, M.O. (2018). Characterization of galvanic sludges waste derived of the metal plating industry from Cariri region, Northeastern of Brazil. Materials Science Forum, 930 MSF, 541-545.

4. Zlebek, T., Hodul, J., \& Drochytka, R. (2018). Repairing composite using hazardous waste containing heavy metals. IOP Conference Series: Materials Science and Engineering, 385 (1), 68-74.

5. Król, A. (2008). Effect of high temperature on immobilization of heavy metals in concrete with an addition of galvanic sludge. WIT Transactions on Ecology and the Environment, 109, 331-339.

6. González-Corrochano, B., Alonso-Azcárate, J., Rodríguez, L., Corvinos, M.D., \& Muro, C. (2016). Valorization of washing aggregate sludge and sewage sludge for lightweight aggregates production. Construction and Building Materials, 116, 252-262.

7. Bednarik, V., Vondruska, M., \& Koutny, M. (2005). Stabilization/solidification of galvanic sludges by asphalt emulsions. Journal of Hazardous Materials, 122 (1-2), 139-145. 
8. Krivenko, P., Petropavlovsky, O., Kovalchuk, O., Pasko, A., \& Lapovska, S. (2018). Design of the composition of alkali activated Portland cement using mineral additives of technogenic origin. Eastern-European Journal of Enterprise Technologies, 4/6 (94), 6-15. 9. Castañeda Bocanegra, J.J., Espejo Mora, E., \& Cubillos, G.I. (2017). González Encapsulation in ceramic material of the metals $\mathrm{Cr}, \mathrm{Ni}$, and $\mathrm{Cu}$ contained in galvanic sludge via the solidification/stabilization method. Journal of Environmental Chemical Engineering, 5 (4), 3834-3843.

10. Ol'shanskaya, L.N., Lazareva, E.N., \& Bulkina, L.A. (2016). Recycling of Heavy Metals and Their Compounds from Galvanic Sludges to Produce Pigments and Fillers and the Active Species of Nickel-Iron (Cadmium) Battery Cathodes. Chemical and Petroleum Engineering, 52 (1-2), 138-142.

11. Vilarinho, C., Teixeira, J., Araújo, J., \& Carvalho, J. (2017). Effect of time and acid concentration on metal extraction from galvanic sludges. ASME International Mechanical Engineering Congress and Exposition, Proceedings (IMECE), 14, 713-720.

12. Kumar, M., Dosanjh, H.S., \& Singh, H. (2019). Biopolymer modified transition metal spinel ferrites for removal of fluoride ions from water. Environmental Nanotechnology, Monitoring and Management, 12, 237-245.

13. Argymbek, B.K., Kichanov, S.E., Kozlenko, D.P., \& Lukin, E.V. (2018). Kristallicheskaja i magnitnaja struktura granulirovannyh poroshkov $\mathrm{Mn}-\mathrm{Zn}$ - i Ni $-\mathrm{Zn}$-ferritov shpinelej. Fizika tverdogo tela, 60 (9), 1683-1688. (in Russian)

14. Kostishin, V.G., Kozhitov, L.V., Vergazov, R.M., Andreev, V.G., \& Morchenko, A.T. (2011). Radiopogloshhajushhij ferrit. Patent RF № 2417268. (in Russian)

15. Hua, S., Huaiwu, Z., Xiaoli, T., \& Yingli, L. (2007). Effects of nanocrystalline ferrite pattieles on densification and magnetic properties of the Ni-Cu-Zn ferrites. J. Mates. Sci, 42, 2849-2853.

16. Kolev, S., \& Koutzarova, T. (2018). Nanosized Ferrite Materials for Absorption of and Protection from MW Radiation. Advanced Nanotechnologies for Detection and Defense against CBRN Agents, 273-284.

17. Özgür, Ü., Alivov, Y., \& Morkoç, H. (2009). Microwave ferrites, part 1: fundamental properties. Journal of Materials Science: Materials in Electronics, 20 (9), 789-834.

18. Gomes, J.A., Azevedo, G.M., Depeyrot, J., Mestnik-Filho, J., \& Paula, F.L. (2012). Structural, chemical, and magnetic investigations of core-shell zinc ferrite nanoparticles. Journal of Physical Chemistry, 116 (45), 24281-24291.

19. Grasset, F., Labhsetwar, N., Li, D., Park, D. C., Saito, N., Haneda, H., Cador, O., Roisnel, T., \& Mornet, S. (2002). Etourneau. Synthesis and Magnetic Characterization of Zinc Ferrite Nanoparticles with Different Environments: Powder, Colloidal Solution, and Zinc Ferrite-Silica Core-Shell Nanoparticles. Langmuir, 18 (21), 8209.

20. Zhang, R., Huang, J., Zhao, J., Sun, Z., \& Wang, Y. (2007). Sol-gel auto-combustion synthesis of zinc ferrite for moderate temperature desulfurization. Energy Fuels, 21, $2682-$ 2687.

21. Kong, L.B., Zhang, T.S., Ma, J., \& Boey, F. (2008). Progress in synthesis of ferroelectric ceramic materials via high-energy mechanochemical technique. Progress in Materials Sci., 53, 207-213.

22. Chen, D.H., \& He, X.R. (2001). Synthesis of nickel ferrite nanoparticles by sol-gel method. Mater. Res. Bull., 36, 1369-1377.

23. Kochetov, G.M., Prikhna, T.O., Samchenko, D.M., \& Kovalchuk, O.Yu. (2019). Development of ferritization processing of galvanic waste with energy saving electromagnetic pulse activation of the process. Eastern-European Journal of Enterprise Technologies, 6/10 (102), 6-14.

24. Kochetov, G., Prihna, T., Kovalchuk, O., \& Samchenko, D. (2018). Research of the treatment of depleted nickel-plating electrolytes by the ferritization method. EasternEuropean Journal of Enterprise Technologies, 3 (6-93), 52-60. 
25. Frolova, L.A., Pivovarov, A.A., \& Baskevich, A.S. (2014). Structure and properties of nickel ferrites produced by glow discharge in the $\mathrm{Fe}^{2+}-\mathrm{Ni}^{2+}-\mathrm{SO}_{4}{ }^{2-}-\mathrm{OH}^{-}$system. Russ $J$ Appl Chem, 87 (8), 1054-1059.

26. Pecharsky, V.K., \& Zavalij, P.Y. (2009). Fundamentals of powder diffraction and structural characterization of materials. 2nd ed. Springer: New York, 741.

27. Rodenas, L.G., Blesa, M.A., \& Morando P.J. (2008). Reactivity of metal oxides: Thermal and photochemical dissolution of $\mathrm{MO}$ and $\mathrm{MFe}_{2} \mathrm{O}_{4}(\mathrm{M}=\mathrm{Ni}, \mathrm{Co}, \mathrm{Zn})$. Reactivity Journal of Solid State Chemistry, 181, 2350-2358.

28. Mansour, A., \& Melendres, C. (1997). X-Ray Absorption Spectra and the Local Structure of Nickel in Some Oxycompounds and Fluorides. Journal de Physique IV Colloque, 7(C2), 1171-1176.

The article was received 28.05.2020 and was accepted after revision 15.07.2020

\section{Самченко Дмитро Миколайович}

кандидат технічних наук, старший науковий співробітник науково-дослідної частини Київського національного університету будівництва і архітектури

Адреса робоча: 03037 Україна, м. Київ, пр. Повітрофлотський, 31

ORCID ID: 0000-0003-3305-8180e-mail: sama30071988@gmail.com

\section{Кочетов Геннадій Михайлович}

доктор технічних наук, професор кафедри хімії Київського національного університету будівництва і архітектури

Адреса робоча: 03037 Україна, м. Київ, пр. Повітрофлотський, 31

ORCID ID: 0000-0003-0041-7335e-mail: gkochetov@gmail.com

\section{Васильсв Олексій}

доктор, професор

Державний університет Східного Теннессі

Адреса робоча: PO Box 70695, Johnson City, TN 37614, USA

ORCID ID: 0000-0003-2687-0672 e-mail: vasiliev@etsu.edu 